\title{
Competence Development and Appraisal in Organizations
}

\author{
J. I. Stoker \\ B. I. J. M. Van der Heijden \\ University of Twente
}

This contribution focuses on the way in which employees and managers perceive themselves and each other. Based on two PhD-projects, one in which differences between self-ratings and supervisor ratings have been studied, and one in which the focus was the differences between team leaders' selfperception and the team members' perception, it was concluded that supervisors and employees have a different view on the competencies and behavior of one another. Some explanations for these results are given. Also, implications for competence development and appraisal of employees and managers will be described.

KEY WORDS: competence appraisal; self-assessments; self-other ratings disagreement; personal development contract.

In organizations, one can detect an expanding attention toward developing the competencies of their human resources (see e.g., Boyatzis, 1982; Prahalad \& Hamel, 1990; Spencer \& Spencer, 1993; Van der Heijden, 1998). This can be concluded from the amount of time and money that is spent on training and development. In The Netherlands, for instance, in 1993, 45 percent of all enterprises in the private sector with 5 or more employees conducted some kind of training. The bigger the enterprise the higher the probability that employees under-

\footnotetext{
Alphabetical order has been chosen because of equal contribution by both authors. Address correspondence to Dr. J. I. Stoker and Dr. B. I. J. M. Van der Heijden, University of Twente, Faculty of Technology and Management, Department of HRM, P.O. Box 217, 7500 AE Enschede, The Netherlands; e-mail: jis@berenschot.com or B.I.J.M. vanderHeijden@sms.utwente.nl.
} 
went some training. In the same year, enterprises spent 3.5 million Dutch guilders on internal and external courses. This sum includes costs of lost working time, training departments and staff, fees of training institutes and compensation of study fees, travelling, and lodging expenses. The costs of courses as a percentage of the labor costs were 1.7 percent. This percentage increases with the enterprise's size (small enterprises 0.7, medium-sized enterprises 1.3 and big enterprises 3.0) (CBS, 1995).

Most competence development activities focus on individuals or peer groups. For managers, for instance, organizations often make use of management development programs, and similar activities are developed for employees. This line of thought is based on the idea that people develop competencies in an environment with peers who have to develop the same competencies.

For the appraisal of competencies, there is a tendency towards the use of multi-rater or 360-degree appraisals of performance (especially manager performance) (see e.g., Cheung, 1999; Yammarino \& Atwater, 1997). In 1996, almost all Fortune 500 firms were using 360degree appraisal (see Yammarino \& Atwater, 1997). The use of these methods is based on the idea that the judgements of several different raters work better than the judgement of just one (supervisor) rating.

Both the development and appraisal of competencies are built on the same foundation. That is, they both make use of one crucial aspect in human functioning, namely the ability to perceive. The development of managers and employees is only useful when people, in their day-to-day working environment, perceive competencies in a same way. Also, the appraisal of competencies is possible, provided that all raters perceive the same competencies in the same way.

Up to now little attention has been paid to the consequences of dissimilarities in competence ratings for the individual career development and the implications of it for training and development in organizations. Both the PhD-study by Van der Heijden (1998) as well as the one by Stoker (1998) are used to ground the idea that special care is needed in order to successfully use competence development and appraisal in organizations. The results of these studies contribute to the ongoing debate concerning the nature of competencies and their use in organizations.

The study by Van der Heijden concentrated on the competencies of employees while the study by Stoker focused on the competencies of managers. Although the studies have been conducted independently and consisted of data from different organizations, they are compara- 
ble in that they both looked at the issue of self-other ratings disagreements (S-ORD) and investigated whether self-ratings were significantly higher compared to other ratings.

Before we elaborate on the outcomes, we will go into the founding ideas of both studies. Finally we will go into a discussion of results and the implications for the use of competence appraisals in organizations.

\section{Differences Between Self-Ratings and Supervisor Ratings for Competence Assessments of Higher Level Employees}

In the first PhD-project (Van der Heijden, 1998) on the measurement and development of competencies or professional expertise, both employees and their supervisors were asked to determine the amount of expertise of the employee, and his/her abilities to further develop it. First, we will describe how expertise has been operationalized and how a measurement instrument has been developed, before we present the results of study number one.

\section{A Multi-Dimensional Operationalization of Professional Expertise}

From the relevant literature we concluded that professional competence is a multi-dimensional concept (see Van der Heijden, 1998). A multi-dimensional operationalization of the concept of professional expertise should comprise the different types of knowledge that are inherent to a certain professional field (Alexander, Schallert \& Hare, 1991), the amount of meta-cognitive knowledge (self-insight or selfconsciousness), and a skills component (Bereiter \& Scardamalia, 1993; Chi, Glaser \& Farr, 1988; Ericsson, 1996; Ericsson \& Smith, 1991).

After a thorough literature study and some in-depth interviews it was concluded that the concept of professional expertise was not fully covered by these three dimensions (Van der Heijden, 1998). Measurement of cognitive abilities and skills is not enough to fully cover the construct of professional development. Motivational aspects and selfinsight, as well as social skills, social recognition and growth capacities are important interactors and moderators (Ericsson \& Lehmann, 1996; Trost, 1993). Thus, there is a compelling reason for the proposal of a broader type of measurement, in which cognitive abilities and overt skills play an explicit, but only a partial role (Van der Heijden, 1997). 
One is only labelled as an expert by virtue of being respected by knowledgeable people in the organization. There are many people who have a vast amount of knowledge and/or skills. However, not all of them are considered as highly skilled or as experts, owing to a lack of social intelligence, communicative skills and so on. This fourth important aspect of professional expertise can be labelled the dimension of acquirement of social recognition (Van der Heijden, 1998).

A fifth dimension that has been added to previous conceptualization frameworks is the dimension of growth and flexibility (Van der Heijden, 1998). People who are capable of acquiring more than one area of expertise within adjacent or radically different fields, or who are capable of acquiring a strategy to master a new area of expertise or expert performance in another territory can be termed 'flexperts' (Van der Heijden, 1996). These are people who are both flexible and in possession of expertise. They are, for example, good at adjusting flexibly to technological changes and they demonstrate that they know how to respond quickly and alertly at times when there are opportunities in adjacent areas.

This fifth dimension in this operationalization of expertise, namely the potential to grow and to adapt flexibly, is most valuable in this context or situation. The individuals who are best prepared for jobs nowadays are the ones who continue studying and who adapt creatively to change.

Hatano and Inagaki (1986; see also Hatano, 1988) correspondingly distinguish between routine (or conventional) expertise and adaptive expertise. Routine experts are outstanding in terms of speed, accuracy, and automaticity of performance but they lack adaptability to new tasks and problems. Salomon and Perkins (1989) make a related distinction between low-road and high-road mechanisms of transfer. Whereas routine experts are able to solve familiar types of problems quickly and accurately, they only have modest capabilities in dealing with novel types of problems. Adaptive experts, on the other hand, may even be able to invent new procedures derived from their expert knowledge.

In the same way Hoyer (1987) differentiates between specialized expertise and flexible expertise. Specialized expertise is based on a relatively narrow domain of knowledge. The accumulation of knowledge in a narrow job may have the effect that the employee has a tendency towards intense specialization and is increasingly incapable of acquiring other types of expertise. 


\section{Method: Instruments and Sample}

For the measurement of professional expertise in study one, a reliable and valid multi-dimensional and domain-independent operationalization has been used (see Van der Heijden (1998, 2000) for a thorough explanation and a discussion of psychometric results).

All employees rated in this study worked in the higher ranks of the organization. In order to collect data from both employees as well as from their direct supervisors, nominally identical questions have been developed. Since quite a number of combined ratings have been collected from both employees and from their immediate supervisors, namely 313 , interesting comparisons between the two sources of raters could be made. The origin of these respondents is described in Table 1.

Results

To investigate whether the assessments of the two sources of raters, employees and their direct supervisors, differ, paired samples comparisons have been made. In Table 2, the outcomes of the paired samples

Table 1

Number and Response Rate of Combined Ratings, per Organization

\begin{tabular}{lc}
\hline Organization & $\begin{array}{c}\text { Number and } \\
\text { Response } \\
\text { Rate Pairs }\end{array}$ \\
\hline Akzo Nobel & $56(17.9 \%)$ \\
Hewlett Packard & $35(11.2 \%)$ \\
Ministry of Justice & $40(12.8 \%)$ \\
Ministry of Transport, Public Works and Water & \\
$\quad$ Management & $40(12.8 \%)$ \\
Philips Communications and Processing Services & $35(11.2 \%)$ \\
Rabobank Organization & $64(20.4 \%)$ \\
Unilever Research Laboratory & $30(9.6 \%)$ \\
University of Twente & $13(4.2 \%)$ \\
& Total: 313 pairs \\
\hline
\end{tabular}




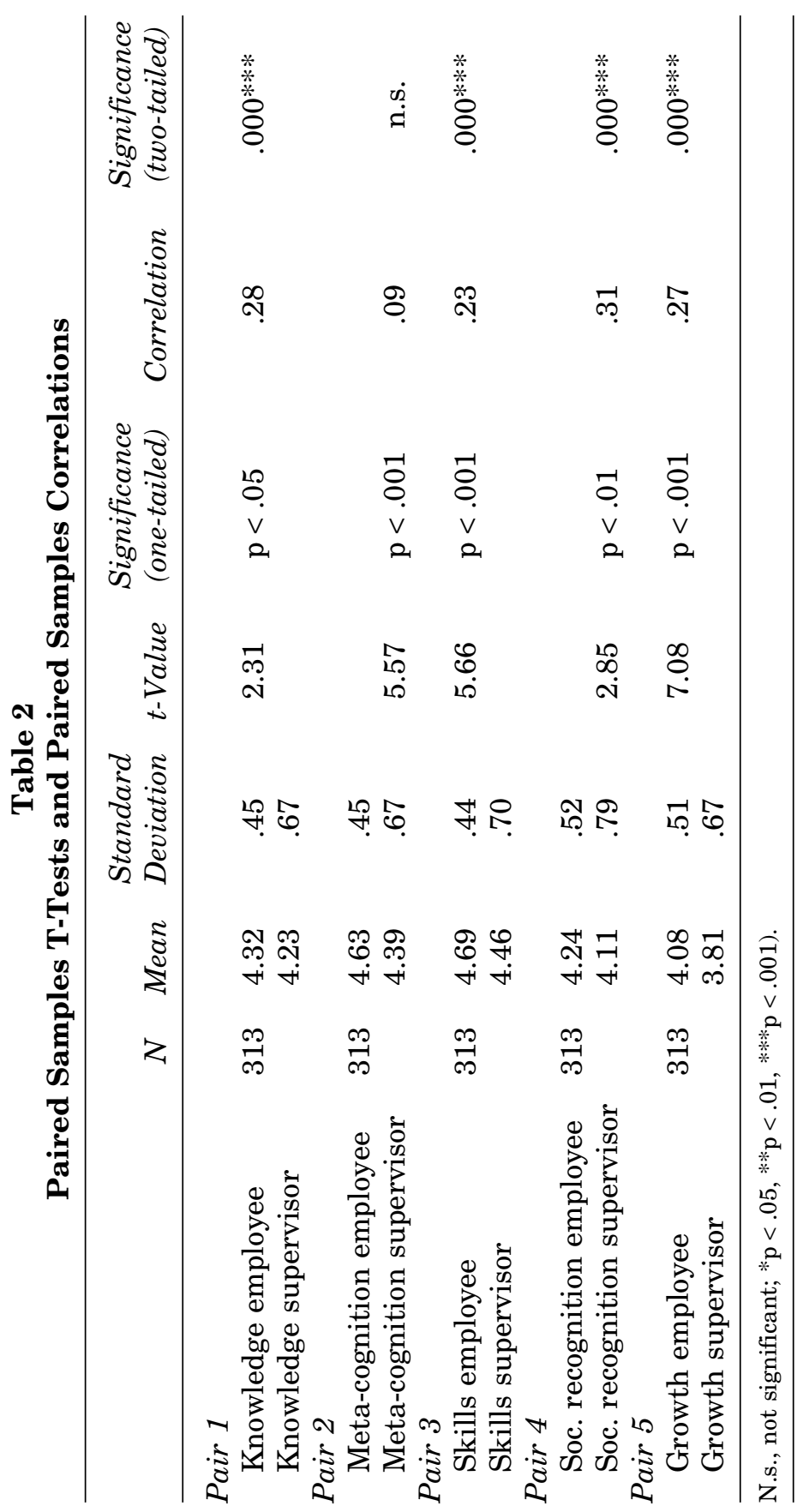


comparisons are given. Extremely on the left-side in the table one can see the five differentiated expertise dimensions (see the previous section for more details).

Table 2 shows that the mean scores of the employees and the supervisors differ significantly. The paired samples T-tests confirm that, for each scale, the self-ratings are significantly higher than the corresponding supervisor ratings. In other words, employees think somewhat better of themselves than their supervisors do, or at least they give a more positive image of themselves.

This so-called leniency-effect (Huber \& Power, 1985; Tsui \& Ohlott, 1988 ) is in accordance with the notion that individuals are motivated by drives of self-enhancement, which lead to emphasizing merits and downplaying faults.

The outcomes concerning the correlations are in accordance with results from comparable studies. Mabe and West (1982) provided an excellent review and meta-analysis of the validity of self-evaluations of ability. Their review of 55 studies including 267 coefficients indicated a mean correlation of .29 between self-reported ability and other ability/performance measurements including tests, grades, supervisory ratings, and, less frequently, performance output. All correlations lie between .23 and .31 . the exception concerns the corresponding ratings on the meta-cognitive knowledge scales which correlate .09 .

A possible explanation of the latter could be the stronger innerdirectedness and self-reflective loading of this attribute. The dimension of meta-cognitive knowledge is perhaps the most difficult personbound factor to assess validly. Supervisors, although responsible, are rather too distant most of the time to know their employees more than superficially. Maybe this is why supervisors seem to be somewhat at a loss when facing meta-cognition.

Besides, it should be remembered that the employees rated in this study work in the higher ranks of their organizations. At these levels, employees and supervisors respect their own separate responsibilities and often only intermittently see and speak to each other. Also, it is known from our previous study (see e.g. Boerlijst, Van der Heijden \& Van Assen, 1993; Van der Heijden \& Boerlijst, 1997) that the period during which supervisors and employees know and have to do with each other, tends to be relatively short, due to a rather high mobility of supervisors.

As a result, there is a lack of interest in the further development of the employee on the part of the management. The instrumental style of leadership, which means that supervisors are only interested in the 
here-and-now functioning of their staff, prevents them from taking care of longer-term questions like employability and life-long learning possibilities.

\section{Competencies of Team Leaders: Self-Ratings Versus Ratings of Team Members}

In the second PhD-project (Stoker, 1998), the focus is on the subject of leadership competencies: do managers rate their leadership competencies significantly higher than their own employees do? Here, the behavior of team leaders towards their self-managing teams was central. Self-managing teams are becoming more and more popular in organizations. From research, we can conclude that especially the leader has to develop an other leadership style in order to lead a selfmanaging team. We will first describe some theoretical backgrounds on these forms of leadership, before we present the results of the study.

\section{Leadership Styles and Self-Managing Teams}

The central idea of leading self-managing teams is that leaders have to take care of the development of teams in such a way, that they facilitate the teams to become self-managing or self-supporting. This asks for different behavior or different competencies of leaders than in the situation before. In the literature on teams (see e.g., Manz \& Sims, 1984; Stewart \& Manz, 1995; Zenger et al., 1994), several leadership styles have been described that could be effective for the development of self-managing teams.

Two crucial styles, according to Stewart and Manz (1995) and Zenger et al. (1994) are initiating structure or directive leadership, and coaching. It is argued that especially beginning teams need guidance and direction (a directive style) from their leaders. Once teams have matured, a more coaching style is needed, in which leaders focus on the development of competencies of team members.

Next to initiating structure and coaching, three other leadership styles, that might be relevant for leading self-managing teams, can be derived from literature on leadership. The first is consideration, which means that leaders emphasize the well-being of employees. The second relevant leadership style is charisma. Charisma means that lead- 
ers have demonstrated an exceptional ability for leadership and that employees trust them. The third relevant style is consultative leadership, which means that leaders delegate tasks toward employees.

The study that is presented in this article investigates how leaders and team members experience these styles, and whether or not team members experience the behavior of their leaders differently compared to their leaders?

\section{Method: Instruments and Sample}

A large-scale survey has been done in two Dutch organizations; the Postbank (a bank organization) and Hoogovens (a steel company, now called Corus). Although the two organizations differ in their production process - that is, one is a service organization whereas the other is an industrial organization-they both implemented self-managing teams based on the same theoretical background. Therefore, the data from both organizations could be compared.

At the Postbank, three departments belonging to one division participated. In total, there were 21 teams working within these departments. The average group size was 13 . There were 11 team leaders; one team leader could lead up to three teams. At Hoogovens, three factories belonging to one division participated. There were 65 teams working within these factories, with an average group size of 15. Each team leader supervised one team.

A questionnaire was used which contained the following five leadership variables: the consideration and initiating structure scales of a Dutch translation of the Ohio State leadership questionnaire (see Mulder et al., 1971), the charismatic leadership scale (Bass, 1985, in Dutch translated by Den Hartog et al., 1994) in combination with a scale that measures Individual Prominence (Mulder et al., 1971), the participative leadership scale of French and Raven (translated in Dutch by Mulder et al., 1986), and a scale for coaching (De Jong \& Carpay, 1991; Le Blanc, 1994), in combination with the scale that measures Individualized Consideration (Bass, 1985, in Dutch translated by Den Hartog et al., 1994) (see Stoker (1998) for a thorough explanation and a discussion of psychometric results).

More than 600 employees in 82 self-managing teams in two organizations and their team leaders filled out the questionnaire. In Table 3 , an overview of the participating companies is given with response rates for employees and team leaders. 
Table 3

Number and Response Rate per Organization (Employees and Team Leaders)

\begin{tabular}{lcc}
\hline \multirow{2}{*}{ Organization } & \multicolumn{2}{c}{ Number and Response Rate } \\
\cline { 2 - 3 } & Employees & Team Leaders \\
\hline Postbank & $242(81 \%)$ & $21(100 \%)$ \\
Hoogovens & $351(38 \%)$ & $42(65 \%)$ \\
\hline
\end{tabular}

Results

First, several team leaders were interviewed. They were selected for the new job by an assessment center procedure. In this assessment center team leaders were tested on the competencies needed for the new job, such as coaching and consultative leadership. In these interviews, all selected team leaders claimed that "they had changed." They stated that, compared to the period before they were team leaders, they had become much more consultative, and that they were now coaches instead of directive supervisors. However, the results of the survey show that team members saw their leaders in a different way. The results in Table 4 show the average score of team members and their leaders of the two organizations on the five leadership styles.

The results depicted in Table 4 show that team leaders perceive themselves differently than their team members. Overall, they see themselves as being more considerate, charismatic, consultative and coaching than their team members. Especially the differences between the scores of team leaders and team members on coaching in both organization $\mathrm{A}$ and $\mathrm{B}$ are considerable.

The results in Table 4 are mean scores of all team leaders and team members. From the results in Table 4 it is not clear whether the differences between the perception of the team and the team leader are significant. In order to answer this question, T-tests for paired samples were conducted. Results are shown in Table 5. The results show that there is little or no correspondence between the perception of team leaders of their own competencies, and the perceptions of their teams. Although the teams have a shared perception of team leaders (as can be concluded from the significant eta-scores), there is, with the exception of directive leadership (initating structure) in organization 
Table 4

Scores on Leadership Competencies in Organization A

(21 Team Leaders, 242 Team Members) and B (42 Team Leaders, 351 Team Members)

\begin{tabular}{|c|c|c|c|c|}
\hline \multirow[b]{3}{*}{ Competencies } & \multicolumn{4}{|c|}{ Scores on Leadership Competencies } \\
\hline & \multicolumn{2}{|c|}{$\begin{array}{l}\text { Organization A } \\
(N=21 \& 242)\end{array}$} & \multicolumn{2}{|c|}{$\begin{array}{l}\text { Organization } B \\
(N=42 \& 351)\end{array}$} \\
\hline & $\begin{array}{c}\text { Team } \\
\text { Leaders }\end{array}$ & $\begin{array}{c}\text { Team } \\
\text { Members }\end{array}$ & $\begin{array}{c}\text { Team } \\
\text { Leaders }\end{array}$ & $\begin{array}{c}\text { Team } \\
\text { Members }\end{array}$ \\
\hline Consi & $3,98(.30)$ & $3,51(.68)$ & $3,81(.42)$ & $3,53(.78)$ \\
\hline Initiating structure & $2,96(.57)$ & $3,37(.67)$ & $3,36(.55)$ & $3,34(.69)$ \\
\hline Charisma & $3,79(.43)$ & $3,35(.67)$ & $3,74(.49)$ & $3,33(.80)$ \\
\hline Consultative & $3,99(.38)$ & $3,37(.57)$ & $3,80(.29)$ & $3,44(.71)$ \\
\hline Coaching & $3,43(.54)$ & $2,72(.70)$ & $3,84(.45)$ & $2,99(.83)$ \\
\hline
\end{tabular}

B, no significant correlation in scores. This means that team leaders see their own competencies completely different than their teams do. The teams have a shared idea of the leadership competencies of leaders, but these ideas do not correspond with the ideas of the leaders.

There are several explanations for these results. First we can refer to the explanation earlier mentioned in this article, namely the leniency-effect. Respondents tend to see themselves in a more positive way than other people do. When team leaders were confronted with the outcomes, they claimed that it could be caused by the fact that team leaders (in organization A) worked at another location than the team members did. This might account for the non-correspondence with their team members' view. Given the fact that these teams were at the time of measurement only operating for three months, this could indeed explain the differences. However, one year later the same results were found in this organization. Again, the team leaders and team members had different perceptions about the competencies of the team leader.

Also, it is possible that the phenomenon of social desirability played a role (see Cascio, 1991; Golden, 1992; Huber \& Power, 1985; Tsui \& Ohlott, 1988). Team leaders in both organizations were aware of the fact that, for a leader of a self-managing team, giving direction is not 
Table 5

Results of the T-Tests for Paired Samples. Bold T-Values are Significant (Two-Tailed) For the Significance of the Correlations: * <.05 (Two-Tailed)

\begin{tabular}{lccc}
\hline & \multicolumn{3}{c}{ Results from the T-test } \\
\cline { 2 - 4 } Leadership Competencies & Eta (sign.) & T-Value (sign., df) Correlation \\
\hline Teams in organization A & & & \\
(N = 21) & & & \\
Consideration & $.55(.000)$ & $\mathbf{5 , 3 9}(.000,20)$ & .07 \\
Initiating structure & $.60(.000)$ & $\mathbf{- 2 , 9 8}(.007,20)$ & -.02 \\
Charisma & $.58(.000)$ & $\mathbf{3 , 3 7}(.003,19)$ & -.15 \\
Consultative & $.50(.005)$ & $\mathbf{6 , 6 6}(.000,20)$ & .21 \\
Coaching & $.52(.001)$ & $\mathbf{4 , 9 6}(.000,20)$ & .03 \\
Teams in organization B & & & \\
(N = 42) & & & \\
Consideration & $.39(.024)$ & $\mathbf{3 , 0 4}(.004, \mathrm{df} 38)$ & .05 \\
Initiating structure & $.39(.030)$ & $0,87(.392, \mathrm{df} 39)$ & $.39 *$ \\
Charisma & $.40(.024)$ & $\mathbf{3 , 8 8}(.000, \mathrm{df} 38)$ & .06 \\
Consultative & $.40(.014)$ & $\mathbf{5 , 2 3}(.000, \mathrm{df} 40)$ & -.04 \\
Coaching & $.49(.000)$ & $\mathbf{9 , 0 0}(.000, \mathrm{df} 38)$ & .10 \\
\hline
\end{tabular}

desirable anymore, but coaching is. The respondents might know the most desirable competencies, and instead of answering the questions truthfully, they give the answers that correspond to the 'ideal' situation.

\section{Discussion}

Based on the results of the two studies presented above, some general conclusions can be drawn. First, it is noteworthy that both studies, from a different perspective, had comparable results. Study one showed that supervisors' ideas about the competencies of their employees and the employees' ideas about their own competencies do not correspond.

Study two made clear that the same goes for the assessment of the competencies of team leaders. Again, there is hardly any relation be- 
tween the perception of the leader and the employees. This brings up an interesting question: Who is right, the persons that rates him or herself, or the other?

Some authors have suggested that key informants may not be able to accurately recall their own past (see Golden [1992]; Huber and Power [1985]; Wolfe and Jackson [1987]). They pointed out that inaccurate recall in retrospective reporting can result from inappropriate rationalizations, oversimplifications, faulty post hoc attributions, and simple lapses of memory. Also, people are naturally motivated to present themselves in a favourable light, i.e., self-assessment suffers from enhancement or inflation bias (Nisbett \& Wilson, 1977).

On the other hand, there is reason to believe that individuals are capable of describing themselves. Despite doubts on the validity of self-assessment and its use in applied research settings, there is reason to believe that individuals are in a good position to make a valid assessment of their own knowledge and capabilities. Persons who are doing the job possess the greatest familiarity with the job and, because of that, can answer questions about the job. Studies examining jobrelated variables have shown that those who possess greater familiarity with the job and the ratee (Kozlowski \& Kirsch, 1987) provide ratings that are more reliable and have fewer errors (Miller, 1996). Who else has a better understanding of a job and one's functioning in it than the employee?

This means that there are arguments pro and con concerning the use of self-ratings. Therefore, the question 'who is right?' can not unanimously be answered. Rather, we suggest that instead of answering the question if self-ratings should be used, we should ask how selfratings could be used successfully in organizations.

\section{Implications: How Can We Successfully Make Use of Self-Other Ratings?}

How can organizations make proper use of self-other ratings? This seems a relevant issue, given the fact that many organizations use instruments that are based on multi-rater input, such as 360-degree feedback. We argue that there are three ways in which self-other ratings are fruitful.

The first concerns communication about the results of self-other ratings. In both studies, it was found that employees and supervisors seldom talk about mutual expectations toward each other. Given this 
result, how can communication on behavior be improved? We think it can start by asking each other regularly for feedback. This can be done by using questionnaires such as ones used in the studies that have been described in this article. With these results, employees and supervisors have enough information to talk about the differences in perception. Communication about the differences can lead to situations in which ideas and images of the competencies are shared.

Another useful application of self-other ratings concerns training and development. We argue that both the employees and the supervisors should be mutually engaged in the development of each others competencies. Based on the results of the two studies, we argue that these training and development programs should be offered in settings in which the two groups are mixed and in which joined activities can take place. In this way, employees and supervisors learn together and collectively develop their competencies. This means that leadership behavior is something that has to be learned on the 'shop floor,' with feedback from employees.

We claim that there is little use to develop leadership skills only in a training center far away from the 'shop floor.' This leads to selfperceptions of leadership competencies ("I am a coach now") that often do not correspond with the perception of employees (see the results of study two). When these skills can be learned 'on the job,' employees function as co-develop partners. The same goes for employees. They should not just learn by means of courses or training programs, but by working together with their supervisors. Supervisors can be 'sponsors' of several assignments in these courses. In this way, a supervisor can help facilitate the development of employees.

A third way to use self-other ratings and to commit both managers and employees to an ongoing use of perceptions of competencies is through the use of a personal development contract. Such a contract means that employees and their supervisors, in the beginning of a calendar year, agree on which competencies should be developed by employees (this can be done by using one of the questionnaires used in our studies). They both commit themselves to use this contract, and evaluate it at the end of the year.

Also, the contract provides activities for both the employee and the supervisor. This means that employees have to develop the competencies that are in the contract, and that supervisors have to support employees by giving them time and resources to develop. In addition supervisors need to gather systematic information on the content and structure of different types of competencies which employees possess. 
By making this a regular part of the relation between supervisors and employees, supervisors will evaluate their behavior on a recurrent base and, and as a result, will recalibrate their own perceptions.

\section{References}

Alexander, P.A., Schallert, D.L., \& Hare, V.C. (1991). Coming to terms: How researchers in learning and literacy talk about knowledge. Review of Educational Research, 61(3), 315-344.

Bass, B.M. (1985). Leadership and performance beyond expectations. New York: The Free Press.

Bereiter, C., \& Scardamalia, M. (1993). Surpassing ourselves. An inquiry into the nature and implications of expertise. Chicago: Open Court.

Boerlijst, J.G., Van der Heijden, B.I.J.M., \& Van Assen, A. (1993). Veertig-plussers in de onderneming [Over-forties in the organization]. Assen: Van Gorcum/Stichting Management Studies.

Boyatzis, R.E. (1982). The competent manager: A model for effective performance. Chichester: Wiley.

Cascio, W.F. (1991). Applied psychology in personnel management. London: PrenticeHall International.

CBS (1995). Bedrijfsopleidingen 1993 [Employer sponsored training 1993]. Voorburg/ Heerlen: Centraal Bureau voor de Statistiek.

Cheung, G.W. (1999). Multifaceted conceptions of self-other ratings disagreement. Personnel Psychology, 52, 1-36.

Chi, M.T.H., Glaser, R., \& Farr, M.J. (Eds.) (1988). The nature of expertise. Hillsdale, NJ: Lawrence Erlbaum Associates.

De Jong, R.D., \& Carpay, M. (1991). Leadership style and group member's mood, job satisfaction and effectiveness. Paper presented at 'the Fifth European Congress on Psychology of Work and Organization'. Rouan, Frankrijk, 24-27 March 1991.

Den Hartog, D., Van Muijen, J., \& Koopman, P. (1994). Transactioneel versus transformationeel leiderschap. Een analyse van de MLQ in de Nederlandse situatie. Gedrag en Organisatie, 7(3), 155-166.

Ericsson, K.A. (1996). The road to excellence. The acquisition of expert performance in the arts and sciences, sports, and games. Mahwah, NJ: Lawrence Erlbaum Associates, Publishers.

Ericsson, K.A., \& Lehmann, A.C. (1996). Expert and exceptional performance: Evidence on maximal adaptations on task constraints. Annual Review of Psychology, 47, 273305.

Ericsson, K.A., \& Smith, J. (1991). Toward a general theory of expertise. Prospects and limits. Cambridge: Cambridge University Press.

Golden, B.R. (1992). The past is the past?-Or is it? The use of retrospective accounts as indicators of past strategy. Academy of Management Journal, 35, 848-860.

Hatano, G. (1988). Social and motivational bases for mathematical understanding. In: G.B. Saxe \& M. Gearhart (Eds.), Children's mathematics (pp. 55-70). San Francisco: Jossey-Bass.

Hatano, G., \& Inagaki, K. (1986). Two courses of expertise. In: H. Stevenson, H. Azuma \& K. Hakuta (Eds.), Child development and education in Japan (pp. 262272). San Francisco: Freeman.

Hoyer, W. (1987). Acquisition of knowledge and the decentralization of $g$ in adult intellectual development. In: C. Schooler \& K.W. Schaie (Eds.), Cognitive functioning and social structure over the life course (pp. 120-141). Norwood, NJ: Ablex. 
Huber, G.P., \& Power, D.J. (1985). Retrospective reports of strategic level managers: Guidelines for increasing their accuracy. Strategic Management Journal, 6, 171-180. Kozlowski, S.W.J., \& Kirsch, M.P. (1987). The systematic distortion hypothesis, halo, and accuracy: An individual-level analysis. Journal of Applied Psychology, 72, 252261.

Le Blanc, P.M. (1994). De steun van de leiding [Support from leaders]. Amsterdam: Thesis Publishers.

Mabe, P., \& West, S. (1982). Validity of self-evaluation of ability: a review and metaanalysis. Journal of Applied Psychology, 67, 280-296.

Manz, C.C., \& Sims, H.P. (1984). Searching for the 'unleader': organizational member views on leading self-managed groups. Human Relations, 37, 409-424.

Miller, M.J. (1996). Rater individual differences and accuracy in performance appraisal. A thesis submitted to the Office of Graduate Studies of Texas A\&M University.

Mulder, M., De Jong, R.D., Koppelaar, L., \& Verhage, J. (1986). Power, situation and leader's effectiveness: an organizational field study. Journal of Applied Psychology, $71,566-570$.

Mulder, M., Ritsema van Eck, J.R., \& De Jong, R.D. (1971). An organization in crisis and non-crisis situations. Human Relations, 24, 19-41.

Nisbett, R.E., \& Wilson, T.D. (1977). Telling more than we can know: Verbal reports on mental processes. Psychological Review, 84, 231-259.

Prahalad, C.K., \& Hamel, G. (1990). The core competence of the corporation. Harvard Business Review, 68(3), 79-91.

Salomon, G., \& Perkins, D.N. (1989). Rocky roads to transfer: Rethinking mechanisms of a neglected phenomenon. Educational Psychologist, 24, 113-142.

Spencer, L.M., \& Spencer, S.M. (1993). Competence at work: models for superior performance. New York: Wiley \& Sons.

Stewart, G.L., \& Manz, C.C. (1995). Leadership for self-managing work teams: a typology and integrative model. Human Relations, 48, 747-770.

Stoker, J.I. (1998). Leidinggeven aan zelfstandige taakgroepen [Leading self-managing teams]. Assen: Van Gorcum (dissertation).

Trost, G. (1993). Prediction of excellence in school, university and work. In: K. Heller, F.J. Mönks \& A.H. Passow (Eds.), International Handbook of Research and Development of Giftedness and Talent (pp. 325-336). Oxford: Pergamon Press.

Tsui, A.S., \& Ohlott, P. (1988). Multiple assessment of managerial effectiveness: interrater agreement and consensus in effectiveness models. Personnel Psychology, 41, 779-803.

Van der Heijden, B.I.J.M. (1996). Life-long expertise development: goal of the nineties. Book of Proceedings of the Fifth Conference on International Human Resource Management. Hyatt Islandia San Diego, California, USA, 24-28 June, 1996.

Van der Heijden, B.I.J.M. (1997). Het meten van expertise; aanzet tot een loopbaaninstrument [Measuring expertise; towards a career instrument]. Tijdschrift voor het Hoger Onderwijs, jaargang 15, nr. 3, 250-264.

Van der Heijden, B.I.J.M. (1998). The measurement and development of professional expertise throughout the career. A retrospective study among higher level Dutch professionals. Ph.D.-thesis. University of Twente, Enschede, the Netherlands. Enschede: PrintPartners Ipskamp.

Van der Heijden, B.I.J.M. (2000). The development and psychometric evaluation of a multi-dimensional measurement instrument of professional expertise. High Ability Studies. The Journal of the European Council for High Ability, 11, 9-39.

Van der Heijden, B.I.J.M., \& Boerlijst, J.G. (1997). Bekwamer door loopbaanontwikkelng; tussen ervaringsconcentratie en ervaringsfragmentatie [More competent through career development; between experience concentration and experience fragmentation]. In: H. Leenen, B. Rosendaal \& H. van der Zee (Eds.), Concurreren op deskundigheid; ervaringen, instrumenten, concepten. Alphen aan den Rijn/ Diegem: Samson Bedrijfsinformatie. 
Wolfe, J., \& Jackson, C. (1987). Creating models of strategic decision making process via participant recall: A free simulation examination. Journal of Management, 13, $123-134$.

Yammarino, F.J., \& Atwater, L.E. (1997). Do managers see themselves as others see them? Implications of self-other rating agreement for human resources management. Organizational Dynamics, 35-44.

Zenger, J.H., Musselwhite, E., Hurson, K., \& Perrin, C. (1994). Leading teams: mastering the new role. Homewood, IL: Business One Irwin. 